\title{
Atrazine Reduces the Critical Period of Weed Interference on NARROW ROW CORN ${ }^{1}$
}

\author{
Atrazine Reduz o Período Crítico de Interferência de Plantas Daninhas em Milho Adensado
}

PADILHA, M. ${ }^{2}$, BARROSO, A.A.M. ${ }^{3}$, CARVALHO, L.B..$^{2,4}$, COSTA, F.R. ${ }^{2}$, and BIANCO, S. ${ }^{3}$

\begin{abstract}
The objective was to determine whether a change occurs in the critical period of weed interference prevention in narrow row corn with the use of atrazine and whether there is influence of the herbicide on crop yield components. The treatments consisted of periods without or with an initial weed control $(0,21,35,49,63,77$, and 91 days after emergence), with or without application of atrazine in spikely post-emergence. The experiment was carried out in a $2 \times 7$ randomized blocks design (with and without weed control and seven periods with three replications). The use or not of atrazine was arranged in a split plot design. The most important weed species were Senecio brasiliensis, Urochloa plantaginea, Conyza bonariensis, Sida rhombifolia, and Solanum spp. Corn yield reduced by $15 \%$ and $18 \%$ with and without application of atrazine, respectively. The number of grains per spike and corn yield were negatively influenced by coexistence with weeds, while the number of rows per spike, the diameter and length of spike were not affected. Corn yield components were not affected by the use of atrazine. The critical period of weed interference prevention was 35 days without atrazine and 23 days with application of atrazine. There is a reduction of the critical period of weed interference prevention on narrow row corn by using atrazine, with no influence of the herbicide on crop yield.
\end{abstract}

Keywords: herbicide, period of coexistence, Zea mays.

RESUMO - O objetivo deste estudo foi verificar se ocorre alteração no período crítico de prevenção à interferência de plantas daninhas em milho adensado com o uso de atrazine e se há influência do herbicida sobre componentes de rendimento da cultura. Os tratamentos consistiram em periodos sem ou com controle inicial de plantas daninhas (0,21, 35, 49, 63, 77 e 91 dias após a emergência), com ou sem aplicação de atrazine em pós-emergência inicial. O experimento foi conduzido em delineamento de blocos casualizados $2 x 7$ (sem e com controle e sete periodos com três repetições). A aplicação ou não de atrazine ocorreu em parcelas subdivididas. As espécies mais importantes de plantas daninhas foram Senecio brasiliensis, Urochloa plantaginea, Conyza bonariensis, Sida rhombifolia e Solanum spp. A redução de produtividade de milho foi de $15 \%$ e $18 \%$ com e sem a aplicação de atrazine, respectivamente, para convivência com a infestação durante todo o ciclo. Apenas o número de grãos por espiga e a produtividade de milho foram influenciados negativamente pela convivência com as plantas daninhas, enquanto o número de fileiras por espiga, o diâmetro e o comprimento da espiga não foram influenciados. Os componentes de rendimento de milho não foram afetados pelo uso de atrazine. O periodo crítico de prevenção à interferência no milho adensado foi reduzido de 35 para 23 dias com a aplicação de atrazine, sem alterar a produtividade final da cultura.

Palavras-chave: herbicida, período de convivência, Zea mays.

Recebido para publicação em 12.4.2016 e aprovado em 20.5.2016.

2 Empresa de Pesquisa Agropecuária e Extensão Rural de Santa Catarina, Rio Fortuna-SC, Brasil. Universidade do Estado de Santa Catarina, Lages-SC, Brasil, <marcelapadilha76@gmail.com>; ${ }^{3}$ Universidade Estadual Paulista, Jaboticabal-SP, Brasil; ${ }^{4}$ Universidade Estadual Paulista, Dracena-SP, Brasil. 


\section{INTRODUCTION}

Corn (Zea mays) crop is sensitive to weed interference, particularly during the early stages of establishment (Kumar et al., 2002). Yield losses caused by this interference can often be over 30\% (Chikoy and Ekeleme, 2003; Hassan et al., 2010) if a satisfactory control of the weed community is not achieved. Weed interference is especially due to competition for environmental resources (such as water, light and nutrients). However, the intensity of such interference depends on factors related to the weed species, crop, management, coexistence period, and soil and weather conditions (Galon et al., 2008). Because these factors are interrelated, the influence of one of them has effects on the others.

Among the factors that affect the degree of interference, the coexistence period is considered one of the most important (Carvalho et al., 2008). As a function of the duration of the coexistence period, the interference periods can be estimated: PBI (period before interference), TPIP (total period of interference prevention) and CPIP (critical period of interference prevention), according to Pitelli and Durigan (1984). The duration of these periods is dependent on management conditions, such as fertilization (Bressanin et al., 2013), irrigation (Adigun, 2005), seeding date (Barroso et al., 2010), crop system (Horta et al., 2004), etc. Application of residual herbicides (such as atrazine) can also affect the CPIP, mainly by altering the local weed community. The hypothesis of this study is that application of atrazine at the early post-emergence of corn planted in narrow rows may reduce the duration of CPIP without a negative effect on crop yield components.

The aim was to determine whether there is: (i) a change in CPIP in narrow row corn with application of atrazine, and (ii) influence of this herbicide on crop yield components.

\section{MATERIAL AND METHODS}

A field experiment was conducted from November 2013 to March 2014 in an experimental area (latitude 27047'18' S, longitude $50^{\circ} 18^{\prime} 09$ ' WGr and altitude $823 \mathrm{~m}$ ), in an Argillaceous Aluminous Humic
Cambisol soil having the following characteristics: 54\% clay; $3.8 \% \mathrm{MO} ; \mathrm{pH}$ (water) $=5.1 ; \mathrm{SMP}=5.0 ; \mathrm{P}, \mathrm{Na}, \mathrm{K}$ contents 2.9 , 10 and $80 \mathrm{mg} \mathrm{dm}^{-3}$, respectively; $\mathrm{Ca}, \mathrm{Mg}, \mathrm{Al}$, $\mathrm{H}+\mathrm{Al}$ and effective CEC 4.63, 3.49, 1.36, 13.0 and $9.68 \mathrm{cmol}_{\mathrm{c}} \mathrm{dm}^{-3}$, respectively; and $\mathrm{Al}$ saturation and bases 14.05 and $37.80 \%$, respectively. Correction of soil acidity and fertilization were performed as recommended by the Brazilian Society of Soil Science (SBCS, 2004).

Hybrid corn seeds P30F53YHR were sown in $50-\mathrm{cm}$ rows width, with an estimated population of 90,000 plants per hectare. The experimental units (subplots) corresponded to four lines with $5 \mathrm{~m}$ in length, totaling $10 \mathrm{~m}^{2}$. For the assessment, the two central lines were considered, disregarding $0.5 \mathrm{~m}$ of each end. The useful area for assessment was $4 \mathrm{~m}^{2}$. To maintain the corn phytosanitary conditions, clorantraniliprole + lambda-cyhalothrin (Ampligo, Syngenta, $15+7,5$ g a.i. ha $^{-1}$ ) insecticides and epoxiconazol + pyraclostrobin fungicides were applied (Opera, Basf, $50+$ 133 g a.i. ha-1).

The treatments studied were represented by two groups, namely: (i) initial periods without weed control, from emergence to harvest; (ii) initial periods with weeds control, from emergence to harvest. The periods corresponded to $0,21,35,49,63,77$ and 91 days after emergence (DAE). In the first group, at the end of each period, the weeds were removed by hoeing. In the second group, weeds hoeing started at emergence and lasted until the end of the period. In each of the groups described, atrazine herbicide was applied in post-emergence, when the corn plant was at stage V3, and the same treatments were performed without herbicide application. Therefore, the experimental design consisted of randomized bocks with 14 treatments (periods with and without weeds control and seven experimental periods) and three replications. Application or non-application of atrazine was allocated to split plots for each treatment.

Atrazine (Primóleo, 400 g e.a. L ${ }^{-1}$; Syngenta) was applied in the morning of December 4, when wind speed was under $3 \mathrm{~km} \mathrm{~h}^{-1}$ and temperature was $18^{\circ} \mathrm{C}$. Five liters ha ${ }^{-1}$ $\left(2 \mathrm{~kg}\right.$ a.i. $\left.\mathrm{ha}^{-1}\right)$ of the herbicide was applied with 
a $\mathrm{CO}_{2}$ pressurized backpack sprayer equipped with flat-fan tips model 8002VS (TeeJet), calibrated to a spray volume of $200 \mathrm{~L} \mathrm{ha}^{-1}$ and $200 \mathrm{kPa}$ pressure.

The weed community was assessed at the end of each initial period without control and at $91 \mathrm{DAE}$ for all initial periods with control, by collecting two samples of plants emerged in an $0.25 \mathrm{~m}^{2}$ area using a $0.5 \times 0.5 \mathrm{~m}$ sampling quadrat thrown at random in the useful area of the subplots. In these periods, the weed species were identified, quantified and collected and then dried in a forced-air oven at $65^{\circ} \mathrm{C}$ for one week to determine the dry weight in a $0.01 \mathrm{~g}$ precision scale. Data related to the weeds occurrence frequency, number of individuals and dry weight were used to calculate the phytosociological indices of Relative Constancy (RCo), Relative Density (RDe), Relative Dominance (RDo) and Relative Importance (RI) of each species following the methodology proposed by Müeller-Dombois and Ellenberg (1974).

At the end of the experimental period, corn spikes were harvested manually at the two central lines of the subplots. The number of grain rows per spike (GRS), number of grains per spike (NGS), spike diameter (SD), spike length (SL) and grain yield (GY) were determined, adjusted to $13 \%$ moisture and converted to $\mathrm{kg} \mathrm{ha}^{-1}$.

Data of crop yield components were analyzed through the F Test (ANOVA) and Tukey's test (means comparison) at 5\% probability level. Additionally, Pearson's correlation test was used for the characteristics assessed, at $5 \%$ probability level. The Statistica ${ }^{\circledR}$ software (version 8.0) was used to perform the tests described.

The periods of interference described by Pitelli and Durigan (1984) were determined through nonlinear regression analysis of the grain yield data using the SigmaPlot ${ }^{\circledR}$ (version 10.0) software. PBI (period before interference) and TPIP (total period of interference prevention) were estimated by means of adjusted curves, considering $5 \%$ of acceptable yield losses; CPIP (critical period of interference prevention) was estimated at the beginning and end of the PBI and at the end of the TPIP.

\section{RESULTS AND DISCUSSION}

Among the species present during the experiment assessment, the most common were Senecio brasiliensis, Urochloa plantaginea, Conyza bonariensis, Sida rhombifolia and Solanum spp. The S. brasiliensis species exhibited the highest values for constancy and relative density indices. Regarding the relative dominance, $U$. plantaginea was the species that exhibited the highest accumulation of biomass per individual (Figure 1). This weed community represents the species most commonly found in corn crops, especially in southern Brazil (Kozlowski, 2002; Martin et al., 2011).

A high density of $S$. brasiliensis plants was found, with high relative importance in the community. The second species in decreasing order of importance, $U$. plantaginea, belongs to the family Poaceae, the same of corn. Belonging to the same family of the crop maximizes the interference effect of the weed species (Page et al., 2012). In general, interference of plants of the family Poaceae has a greater negative effect on the corn plant development, which explains the drop of corn yields found in the experiment (Faria et al., 2014).

Application of the atrazine herbicide did not change corn yields when the crop was free from the interference of weeds (hoed plots), indicating that it did not cause poisoning of the culture (Table 1). The interference levels of the present community were different as to the herbicide application. By coexisting with weeds for 91 days, the corn crop had its final yield reduced by $15 \%$ and $18 \%$ with and without atrazine application, respectively (Table 1 and Figure 2). These values are low if compared to the majority of studies conducted with narrow row corn crops, in which interference exceeds $70 \%$ of reduction of grain yield (Kozlowski, 2002; Massing et al., 2003; Mahmoodi and Rahimi, 2009).

$U$. plantaginea exhibited a fast initial increase in allocating resources to its root system, improving the plant attachment to the ground and facilitating competition for water and nutrients, which explains the RI found even at low density in the infesting 


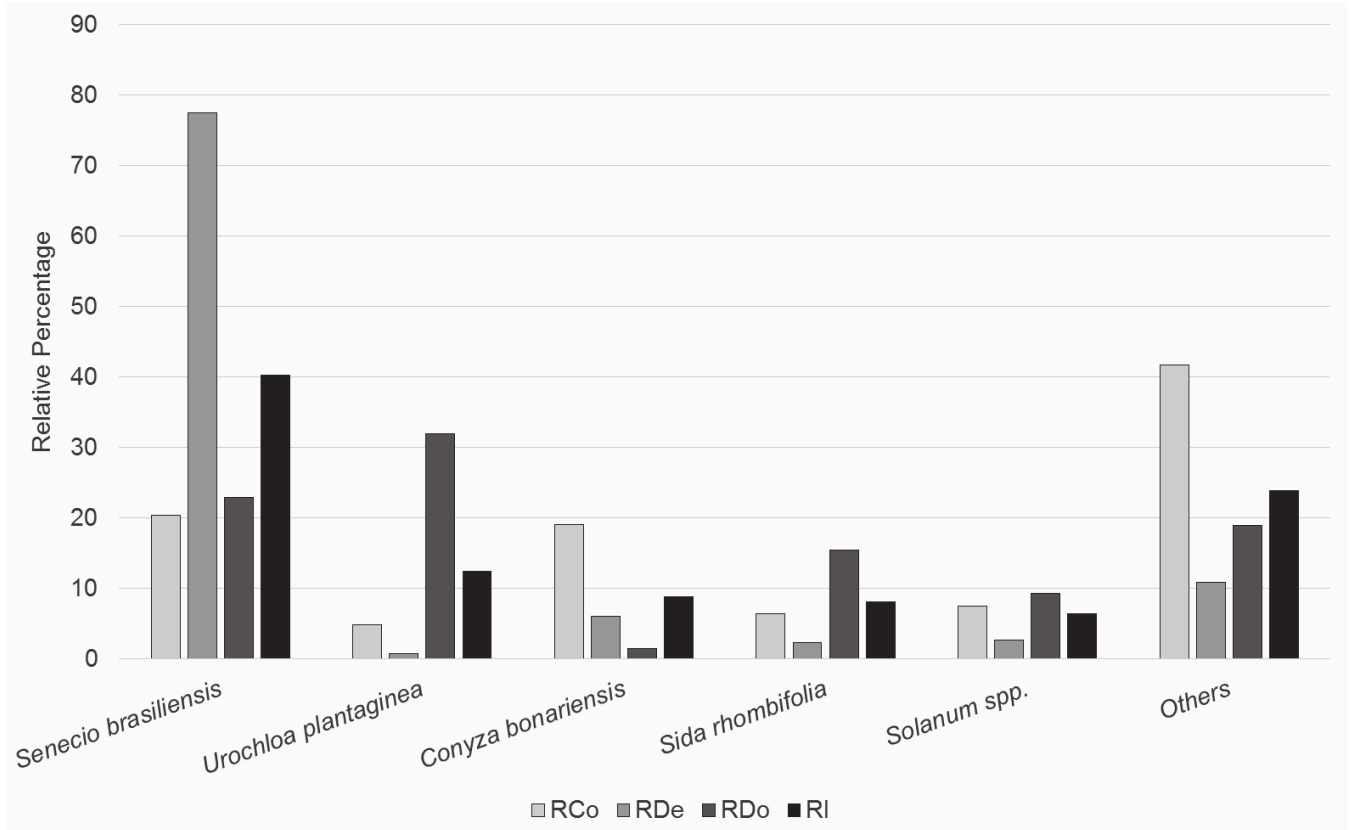

Figure 1 - Phytosociological indices of relative constancy $(\mathrm{RCo})$, relative density (RDe) relative dominance (RDo) and relative importance (RI) of the weed species mostly found in the experiment periods.

community. In addition, this species exhibits greater accumulation of nitrogen, potassium, magnesium and sulfur per biomass unit than corn (Carvalho et al., 2007). However, even with such fast development, low densities of $U$. plantaginea seemed not to affect greatly the final corn yields, as observed in this and other studies, as the one conducted by Spader and Vidal (2000).

The number of rows per spike, spike diameter and spike length did not change as a result of the different periods of coexistence and weeds control, as well as with or without atrazine application (Table 1). The number of grains per spike decreased as the period of coexistence with weeds increased, reaching values higher than $30 \%$. Characteristics such as the spike diameter and spike length in general are not affected when corn plants and weeds coexist, corroborating the data found in this study. Other studies report a harmful effect of the weeds community on the number of spikes produced per plant and a significant correlation between such reduction and yield decline (Galon et al., 2008; Faria et al., 2014). With longer periods of control of the weeds community, the number of seeds per spike was greater. Atrazine application did not cause an effect on the variables observed.
The final corn yield indicated positive correlations with the number of grains per spike, spike diameter and spike length. The number of rows per spike did not show a correlation with the final crop yield (Table 2). These results differ from those observed when the corn plant coexisted with $U$. plantaginea in conventional rows spacing, where all characteristics were negatively affected by the coexistence of species, indicating that narrow row planting favored the development of the corn plants compared with the weeds community (Galon et al., 2008).

Application of atrazine delayed the start of the weeds interference with the corn culture. The periods observed prior to the weeds interference (PBI) were 22 and 32 days, with and without atrazine, respectively 2 ). Application of atrazine also delayed the germination and/or development of the weed species so that the culture gained ten days without weeds interference. The total periods of weeds interference prevention were 57 and 55 days with and without atrazine, respectively, and in the increasing periods of control no significant differences were found (Figure 2).

The critical period of interference prevention (CPIP) of weeds on corn - period in 
Atrazine reduces the critical period of weed interference ...

Table 1 - Number of grain rows per spike (NRS), number of grains per spike (NGS), spike diameter (SD), spike length (SL) and grain yield (GY) of corn grown with and without atrazine application as a function of increasing coexistence periods and weeds control

\begin{tabular}{|c|c|c|c|c|c|c|}
\hline $\begin{array}{l}\text { Period } \\
\text { (Days) }\end{array}$ & Atrazine & $\begin{array}{l}\text { NRS } \\
\text { (unit) }\end{array}$ & $\begin{array}{l}\mathrm{NGS}^{1 /} \\
\text { (unit) }\end{array}$ & $\begin{array}{c}\mathrm{SD} \\
(\mathrm{mm})\end{array}$ & $\begin{array}{c}\mathrm{SL} \\
(\mathrm{mm})\end{array}$ & $\begin{array}{c}\mathrm{GY}^{\underline{1}} \\
\left(\mathrm{~kg} \mathrm{ha}^{-1}\right)\end{array}$ \\
\hline \multicolumn{7}{|c|}{ Coexistence periods } \\
\hline \multirow{2}{*}{0} & YES & 17 & $446 \mathrm{ab}$ & 50.4 & 166.8 & $12339 a$ \\
\hline & $\mathrm{NO}$ & 16 & $468 \mathrm{a}$ & 50.3 & 162.1 & $12182 \mathrm{a}$ \\
\hline \multirow{2}{*}{21} & YES & 16 & $430 \mathrm{bc}$ & 49.6 & 154.6 & $11830 \mathrm{ab}$ \\
\hline & $\mathrm{NO}$ & 17 & $443 \mathrm{~b}$ & 50.0 & 152.5 & $11820 \mathrm{ab}$ \\
\hline \multirow{2}{*}{35} & YES & 17 & $403 \mathrm{~cd}$ & 49.5 & 154.3 & $11716 \mathrm{ab}$ \\
\hline & $\mathrm{NO}$ & 16 & $403 \mathrm{~cd}$ & 49.3 & 149.3 & $10778 \mathrm{~cd}$ \\
\hline \multirow{2}{*}{49} & YES & 17 & 378 def & 49.1 & 148.1 & $11243 \mathrm{bc}$ \\
\hline & $\mathrm{NO}$ & 16 & $390 \mathrm{de}$ & 49.3 & 146.9 & $10764 \mathrm{~cd}$ \\
\hline \multirow{2}{*}{63} & YES & 16 & 364 def & 48.5 & 146.9 & $10782 \mathrm{~cd}$ \\
\hline & $\mathrm{NO}$ & 17 & $362 \mathrm{ef}$ & 48.6 & 142.5 & $10166 \mathrm{def}$ \\
\hline \multirow{2}{*}{77} & YES & 16 & $356 \mathrm{ef}$ & 48.1 & 146.3 & $10647 \mathrm{cde}$ \\
\hline & $\mathrm{NO}$ & 16 & $352 \mathrm{ef}$ & 47.8 & 138.8 & $9495 \mathrm{f}$ \\
\hline \multirow{2}{*}{91} & YES & 16 & $349 \mathrm{f}$ & 47.0 & 136.1 & $10482 \mathrm{cde}$ \\
\hline & $\mathrm{NO}$ & 16 & $339 \mathrm{f}$ & 47.8 & 135.7 & 9975 ef \\
\hline $\mathrm{VC} \%$ & & 8 & 21 & 12 & 16 & 18 \\
\hline \multicolumn{7}{|c|}{ Control periods } \\
\hline \multirow{2}{*}{0} & YES & 17 & 371 ef & 47.2 & 138.7 & $10106 \mathrm{fg}$ \\
\hline & $\mathrm{NO}$ & 16 & $360 \mathrm{f}$ & 49.2 & 135.0 & $10138 \mathrm{fg}$ \\
\hline \multirow{2}{*}{21} & YES & 16 & $378 \mathrm{def}$ & 48.2 & 143.2 & $9660 \mathrm{~g}$ \\
\hline & $\mathrm{NO}$ & 17 & 375 def & 49.7 & 135.9 & $10065 \mathrm{fg}$ \\
\hline \multirow{2}{*}{35} & YES & 17 & 399 cde & 48.8 & 145.4 & $10372 \mathrm{efg}$ \\
\hline & $\mathrm{NO}$ & 16 & 383 def & 49.8 & 142.5 & $10186 \mathrm{fg}$ \\
\hline \multirow{2}{*}{49} & YES & 17 & $400 \mathrm{~cd}$ & 48.9 & 145.5 & $11200 \mathrm{~cd}$ \\
\hline & $\mathrm{NO}$ & 17 & $388 \mathrm{def}$ & 49.9 & 144.2 & $10678 \mathrm{def}$ \\
\hline \multirow{2}{*}{63} & YES & 16 & $403 \mathrm{~cd}$ & 49.6 & 148.7 & $11505 \mathrm{bc}$ \\
\hline & $\mathrm{NO}$ & 16 & $419 \mathrm{bc}$ & 50.5 & 147.6 & $11062 \mathrm{cde}$ \\
\hline \multirow{2}{*}{77} & YES & 16 & $445 \mathrm{ab}$ & 50.7 & 149.9 & $12295 \mathrm{a}$ \\
\hline & $\mathrm{NO}$ & 16 & $420 \mathrm{bc}$ & 51.2 & 152.5 & $11337 \mathrm{bcd}$ \\
\hline \multirow{2}{*}{91} & YES & 17 & $445 \mathrm{ab}$ & 51.2 & 153.1 & $11914 \mathrm{ab}$ \\
\hline & $\mathrm{NO}$ & 17 & $467 \mathrm{a}$ & 51.3 & 160.5 & $11478 \mathrm{bc}$ \\
\hline $\mathrm{VC} \%$ & & 6 & 18 & 12 & 15 & 17 \\
\hline
\end{tabular}

Means followed by different letter in each column are not significantly different by the Tukey's test at $5 \%$

which the infesting community interfered negatively with the crop - was 35 days without the use of atrazine and 23 days with application of the herbicide. This period corresponds to the control period, starting on the third or fifth week after emergence of the culture and lasting until the eighth week. These initial control values (PBI) are higher than those found in literature, because of the narrow row condition. Studying these periods of corn crops coexisting exclusively with
U. plantaginea plants, the CPIP found was 16 days (Galon et al., 2008). In general, this control period starts early, in the first weeks of cultivation (Ferrero et al., 1996; Kozlowski, 2002; Dogan et al., 2004).

These results show that even with the low development of the interfering plants present, such as $S$. brasiliensis and C. bonariensis, and the low levels of interference of these weeds in the culture (around 15\%), the critical 
Table 2 - Correlation between the number of grain rows per spike (NRS) number of grains per spike (NGS), spike diameter (SD), spike length (SL), and grain yield (GY) of corn grown without atrazine application (above diagonal) and with atrazine application (below diagonal) as a function of increasing coexistence periods and weeds control

\begin{tabular}{|c|c|c|c|c|c|}
\hline \multirow{2}{*}{ Variable } & NRS & NGS & $\mathrm{SD}$ & $\mathrm{SL}$ & GY \\
\hline & \multicolumn{5}{|c|}{ Coexistence periods } \\
\hline NRS & - & $0.107^{\mathrm{ns}}$ & $0.160^{\mathrm{ns}}$ & $0.017^{\mathrm{ns}}$ & $0.240^{\mathrm{ns}}$ \\
\hline NGS & $0.042^{\mathrm{ns}}$ & - & $0.882 * *$ & $0.968 * *$ & $0.915^{* *}$ \\
\hline SD & $0.098^{\mathrm{ns}}$ & $0.801 * *$ & - & $0.906 * *$ & $0.916^{* *}$ \\
\hline SL & $0.019^{\mathrm{ns}}$ & $0.816^{* *}$ & $0.904 * *$ & - & $0.864 * *$ \\
\hline \multirow[t]{2}{*}{ GY } & $0.131^{\mathrm{ns}}$ & $0.955 * *$ & $0.885 * *$ & $0.858 * *$ & - \\
\hline & \multicolumn{5}{|c|}{ Control periods } \\
\hline NRS & - & $0.187^{\mathrm{ns}}$ & $0.199^{\mathrm{ns}}$ & $0.186^{\mathrm{ns}}$ & $0.193^{\mathrm{ns}}$ \\
\hline NGS & $0.189^{\mathrm{ns}}$ & - & $0.849 * *$ & $0.933 * *$ & $0.815^{* *}$ \\
\hline SD & $0.142^{\mathrm{ns}}$ & $0.931 * *$ & - & $0.874 * *$ & $0.848^{* *}$ \\
\hline SL & $0.136^{\mathrm{ns}}$ & $0.818^{* *}$ & $0.963 * *$ & - & $0.867^{* *}$ \\
\hline GY & $0.128^{\mathrm{ns}}$ & $0.788^{*}$ & $0.752 * *$ & $0.652 *$ & - \\
\hline
\end{tabular}

** e * Significant at $1 \%$ and $5 \%$ probability, respectively, by Pspikeson's correlation test.

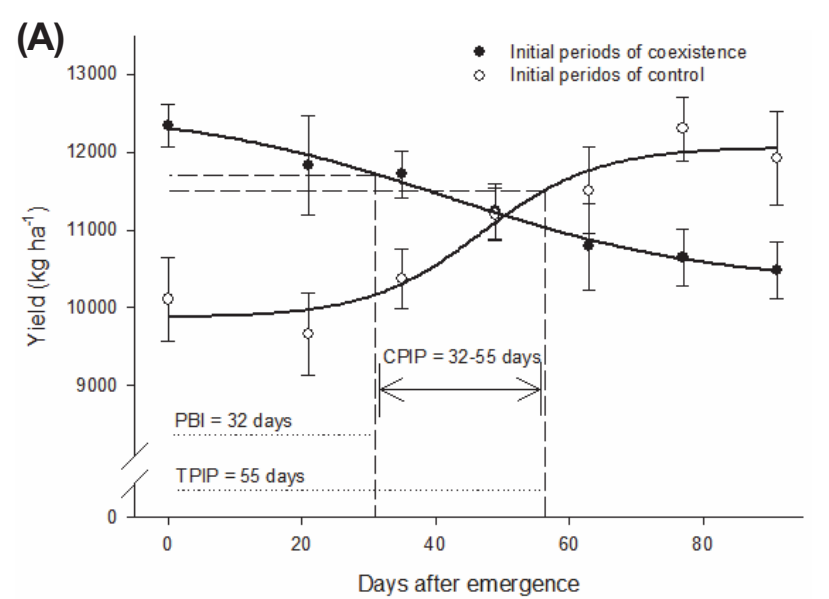

Coexistence: $y=10,290.34+2,262.50 /\left\{1+e^{[-(x-41.61) / 20.10]}\right\}-R^{2}=0.99^{*}$

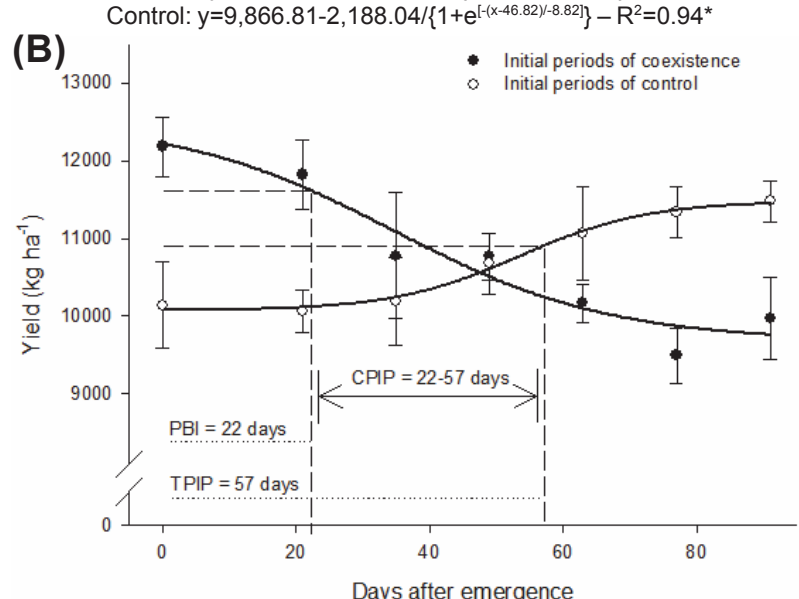

Coexistence: $y=12,511.83-2,839.78 /\left\{1+e^{[-(x-34.75) / 16.21]}\right\}-R^{2}=0.93^{*}$ Control: $y=10,065.65+1,406.32 /\left\{1+\mathrm{e}^{[-(x-53.35) / 9.55]}\right\}-\mathrm{R}^{2}=0.99^{* *}$

Figure 2 - Relation of corn yields with atrazine application (A) and without atrazine application (B) at early postemergence, with an increase in the initial periods without weed control (A) and with control. period diminished by almost two weeks with application of atrazine. Still, the control of plants such as $C$. bonariensis with atrazine is one of the alternatives, but not the only one, in the management of the weeds resistance to herbicides such as glyphosate. However, constant use of atrazine is not recommended due to the harmful effects to the environment; therefore, herbicides rotation with different mechanisms of action is always recommended (Ying et al., 2005). Narrow row corn enhances the potential competition of this culture with the infesting community through the management of this culture. The use of various methods of control is vitally important in the long-term management of weeds, as already reported in literature (Swanton and Weise, 1991).

The conclusions of this study are that there was a decreased CPIP in high density corn crops when the atrazine herbicide was applied at the early stages of post-emergence of the culture and that there was no influence of this herbicide on the corn yield components.

\section{ACKNOWLEDGEMENTS}

The authors gratefully acknowledge the financial support granted by FAPESC for the project development; the MS scholarship granted by CAPES to the first author, and the scholarship on research productivity granted by CAPES to the third author. 


\section{REFERENCES}

Adigun J.A. Critical period of weed interference in rainfed and irrigated tomatoes in the Nigerian savanna. Agric Trop Subtr. 2005;38:73-8.

Barroso A.A.M. et al. Interferência entre espécies de planta daninha e duas cultivares de feijoeiro em duas épocas de semeadura. Bragantia. 2010;69:609-16.

Bressanin F.N. et al. Influência da adubação nitrogenada sobre a interferência de plantas daninhas em feijoeiro. Rev Ceres. 2013;60:43-52.

Carvalho L.B. et al. Interferência e estudo fitossociológico da comunidade infestante na cultura da beterraba transplantada. Acta Sci Agron. 2008;30:325-31.

Carvalho L.B. et al. Estudo comparativo do acúmulo de massa seca e macronutrientes por plantas de milho var. BR-106 e Brachiaria plantaginea. Planta Daninha. 2007;25:293-301.

Chikoye D., Ekeleme F. Cover crops for cogongrass management and effects on subsequent corn yield. Weed Sci. 2003;51:792-7.

Dogan M.N. et al. Determination of optimum weed control timing in maize (Zea mays L.). Turkish J Agric For. 2004;28:349-54.

Faria R.M. et al. Weed interference on growth and yield of transgenic maize. Planta Daninha. 2014;32:515-20.

Ferrero A. et al. Critical period of weed interference in maize. In: Proceedings $2^{\text {nd }}$. International Weed Control Congress. Copenhagen: IWSC, 1996. p.171-6.

Galon L. et al. Interference periods of Brachiaria plantaginea in corn crops on Southern Rio Grande do Sul. Planta Daninha. 2008;26:779-88.

Hassan G. et al. Integrating cultivars with reduced herbicides rates for weed management in maize. Pakistan $\mathbf{J}$ Bot. 2010;42:1923-9.

Horta A.C.S. et al. Interferência de plantas daninhas na beterraba transplantada e semeada diretamente. Acta Sci Agron. 2004;26:47-53.
Kozlowski L.A. Critical period of weed interference in corn crop based on crop phenology. Planta Daninha. 2002;20:365-72.

Kumar S.M.S. et al. Studies on the effect of major nutrients and crop weed competition period in maize. Indian $\mathbf{J}$ Weed Sci. 2002;34:309-10.

Mahmoodi S., Rahimi A. Estimation of critical period for weed control in corn in Iran. World Acad Sci Eng Technol. 2009;49:67-72.

Martin T.N. et al. Perfil do manejo da cultura do milho no sudoeste do Paraná. Rev Ceres. 2011;58:1-8.

Massing R.A. et al. Water use and light interception under Palmer amaranth and corn competition. Weed Sci.

2003;51:523-31.

Müeller-Dombois D., Ellenberg H. Aims and methods of vegetation ecology. New York: John Wiley \& Sons, 1974 $547 \mathrm{p}$.

Page E.R. et al. Why spikely season weed control is important in maize. Weed Sci. 2012;60:423-30.

Pitelli R.A., Durigan, J.C. Terminologia para períodos de controle e de convivência das plantas daninhas em culturas anuais e bianuais. In: Resumos do $15^{\circ}$. Congresso *Brasileiro de Herbicidas e Plantas Daninhas. Piracicaba: SBHED, 1984. p.37.

Sociedade Brasileira de Ciência do Solo - SBCS. Comissão de Química e Fertilidade do Solo - CQFS. Manual de adubação e calagem para os Estados do Rio Grande do Sul e Santa Catarina. Porto Alegre: 2004. 400p.

Spader V., Vidal R.A. Brachiaria plantaginea interference in the agronomic characteristics, yield components and grain yield of corn. Planta Daninha. 2000;18:465-70.

Swanton C.J., Weise Sf. Integrated weed management: the rationale and approach. Weed Technol. 1991;5:657-63.

Ying G.G. et al. Release and behavior of triazine residues in stabilized contaminated soils. Environ Poll. 2005;134:71-7. 